\title{
Constructing Vegetation Database Useful for Assessing Impact of Climate Changes in Japan
}

\author{
Nobuyuki TANAKA, Tetsuya MATSUI, Kazunori SHIMADA, \\ Tsutomu YAGIHASHI, and Hirosi TAODA \\ Forestry and Forest Products Research Institute (FFPRI), P.O.Box 16, Tsukuba Norin, Ibaraki 305-8687, Japan
}

\begin{abstract}
In order to assess the impact of anticipated climate changes on the distribution of plant species and vegetation, it is important to predict potential habitats on national, regional and landscape scales under the current and future climatic conditions. Using the NSNE 3rd mesh vegetation database (MVDB) at ca. $1-\mathrm{km}$ mesh, statistical distribution models were developed to predict potential distributions for buna (Fagus crenata) forests and mizunara (Quercus mongolica var. grosseserrata) forests, and also for buna forests under the current climate and the climate change scenario CCSR/NIES in the 2090s. These studies showed that MVDB was useful to predict the potential distribution of the forest types on a nation-wide scale. However, MVDB has some disadvantages for more detailed analysis due to lack of information on plant species distribution, misidentification of vegetation types, different classification systems of vegetation types among prefectures and coarse spatial resolution. We have been constructing a database (PRDB), which consists of over 8,400 relevé data collected by various authors, to compensate for the disadvantages of MVDB. PRDB has advantages in terms of information on species composition of plant communities. We expect PRDB to enable us to analyze distributional relationships between various plant species and environmental factors on different spatial scales.
\end{abstract}

Key words: Fagus crenata, Phytosociological relevé, Potential habitat distribution, Spatial resolution, Statistical models

\section{Introduction}

In order to assess the impact of anticipated climate changes on the distribution of plant species and vegetation, it is important to predict their potential habitat distributions on national, regional and landscape scales under the current and future climatic conditions. By comparing potential and actual distributions, the sensitivity and vulnerability of plant species and vegetation can be evaluated.

Statistical models predicting the potential habitat distribution of plant species or vegetation types were developed in the USA (Iverson and Prasad 1998), New Zealand (Leathwick 1995), Europe (Guisan and Theurillat 2000), and Japan (Yagihashi et al. 2003, Matsui et al. 2004a, 2004b, 2004c, 2004d). In these studies, the spatial distribution of environmental factors and plant species (or vegetation types) were analyzed to develop models. Statistical models such as generalized linear models (GLMs), generalized additive models (GAMs), tree-based models (TMs), and logistic regression models have been prepared along with developing computer technology. It is not easy to obtain sufficient data sets useful for the modeling studies in a variety of areas. In particular, it is often difficult to obtain information on the distribution of plant species (vegetation types), and even if available, low spatial resolution and the non-statistical sampling methods for data make the analysis difficult.

The databases on the distribution and dominance of plant species (or vegetation types) have been constructed and used for analyses in some countries. In the eastern USA, the Eastwide DataBase (EWDB), which comprises more than 100,000 plots and records for nearly three million trees, was used to predict potential distribution of 80 tree species under current and future climate (Iverson and Prasad 1998, Iverson et al. 1999). In the western USA, presence-absence data on plant distribution digitized on a $25-\mathrm{km}$ grid from available distribution maps were used to predict the potential distribution of tree and shrub species under the current and future climates (Thompson $e t$ al. 1998, 1999). In southern California, the data on the coverage of plant species in three National Forests were used to predict the potential distribution of shrub species (Franklin 1998). In New Zealand, the data from National Forest Survey (NFS), which comprise 15,000 plots, each 0.4 ha in area, and the data from catchments surveys, which comprise 4,000 plots, each $0.04 \mathrm{ha}$, were used to predict potential distributions of tree species under the current and future climates (Leathwick 1995, Leathwick et al. 1996). National Vegetation Survey Database (NVS), which comprises more than 80,000 plots, each ca. $400 \mathrm{~m}^{2}$, was used to predict potential distributions of fern species in New Zealand (Lehmann et al. 2002). In Switzerland, the 
data of the Swiss National Forest Inventory (NFI) were used to predict tree species distribution (Bolliger et al. 2000), and the data of ca. 7,500 phytosociological relevés were used to predict the potential natural forest vegetation types (Brzeziecki et al. 1993). In Japan, the use of a vegetation database is shown in the following.

\section{Studies Using the NSNE 3rd Mesh Vegetation Database (MVDB)}

The 3rd mesh vegetation database (MVDB), which is based on printed vegetation maps $(1: 50,000)$ made under the third National Survey on the Natural Environment (NSNE) by the Ministry of the Environment, is a systematically prepared vegetation database covering the whole of Japan (Anon 1988). The NSNE printed vegetation maps were made from aerial photographs and ground truthing between 1979 and 1986. These maps were summarized on a 30" latitude $\times 45$ " longitude $\left(\right.$ ca. $1 \mathrm{~km}^{2}$ ) Standard Area Grid (Anon. 1998), using the small circle method, each grid square being assigned representative vegetation according to the predominant vegetation within a circle of $125-\mathrm{m}$ radius centered on each square. The database comprises more than the 345,000 grid squares covering the whole of Japan.

Using MVDB and associated climatic data, statistical distribution models successfully predicted potential distributions for two natural forest types on a nation-wide scale. The classification tree analysis for buna (Fagus crenata) forests revealed that four climatic variables affect the current distribution of buna forests, and the potential distribution map of buna was depicted (Matusi et al. 2004a). This method was applied to predict the potential distribution of buna forests under the CCSR/NIES climate change scenario in the 2090s (Fig. 1), resulting in maps of vulnerability and sensitivity of buna forests (Matsui et al. 2004b). The analysis on two predominant natural forest types in the cool-temperate zone, buna forests and mizunara (Quercus mongolica var. grosseserrata) forests, showed that the macro-scale distributions of the two forest types were accurately distinguished by four climatic variables (Yagihashi et al. 2003). The analyses on buna forests were successful because the grid squares of the buna forest were well identified in MVDB. Buna forests have been well recognized by surveyers as climax forests in Japan. However, the study using MVDB may not be as successful for the other types of vegetation as it was for the buna forest type because the grid squares of other vegetation types do not seem to be identified as accurately as in the buna forest type. Moreover, MVDB provides information on the distribution of vegetation types, but not on that 'of plant species. The advantages and disadvantages of the MVDB are summarized as follows:

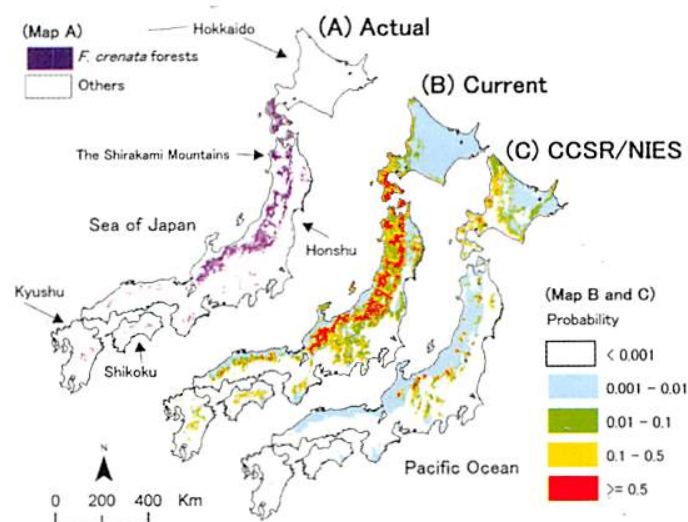

Fig. 1. (A) actual distribution and predicted probability distributions of (B) buna (Fagus crenata) under the current climate and $(\mathrm{C})$ the CCSR/NIES climate change scenario in the 2090s (modified from Matsui et al. 2004b).

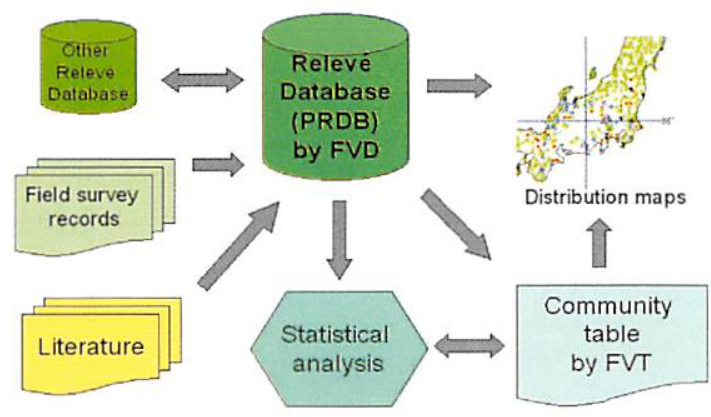

Fig. 2. Scheme of phytosociological relevé database (PRDB) operated by the software, FVD and FVT.

Advantages of MVDB:

1. MVDB provides distributions of vegetation types for more than 345,000 squares, which cover the whole nation.

2. The vegetation types in every $1-\mathrm{km}$ square can be easily linked to environmental data sets, and their relationships can be analyzed.

Disadvantages of MVDB:

1. Lack of information on individual species distributions.

2. Classification of vegetation is inconsistent among the 47 prefectures.

3. Names of vegetation types do not always indicate the dominant species.

4. There is misidentification of vegetation types for some squares due to their similar appearance such as between konara (Quercus serrata) forests and mizunara forests.

5. MVDB represents the actual distribution of vegetation affected by past human activities. Occurrence probability of natural vegetation types 
can be underestimated in areas with an intensive human influence.

6. The two main silvicultural tree species, sugi (Cryptomeria japonica) and hinoki (Chamaecyparis obtusa), are not distinguished when identifying vegetation types. The two species, which differ in their suitable sites, growth rate and economical value, cover $68 \%$ of the whole artificial forest area.

7. The grid squares of fragmented vegetation types such as warm-temperate lucidophyll forest types are few because the spatial resolution of MVDB is coarse for such vegetation types.

\section{Phytosociological Relevés Database (PRDB)}

Phytosociological relevé data compensate for the disadvantages of MVDB throgh being most useful in studies on impact assessments of climate changes in Japan. The relevé data were collected with a consistent method (Braun-Blanquet 1964) for every type of vegetation from all over Japan for the last 50 years, and were accumulated in various sources. If the phytosociological relevés database (PRDB) is constructed, it will enable us to parameterize models predicting potential distribution of various plant species under the current climate as well as under a changed climate (Tanaka 2003). Compared with MVDB, PRDB has the following advantages and disadvantages.

\section{Advantages of PRDB:}

1. PRDB provides information on plant community such as stratification, vegetation cover, and coverage of each species in each relevé.

2. PRDB provides environmental information on location, topography, geology and soil for each relevé.

\section{Disadvantages of PRDB:}

1. The relevé data vary in accuracy due to the different surveyors and objectives.

2. Irregularity of relevés in location and density makes statistical analysis more difficult.

In order to use relevé data for studies on assessing the impact of climate changes, we have been constructing PRDB, which at present consists of over 8,400 relevé data collected by various authors including ourselves (Fig. 2). PRDB is operated by two free software programs, FVD and FVT as Database Management System compiled by $\mathrm{H}$. Taoda (http://cse.ffpri.affrc.go.jp/taoda/veg/index.html).

FVD is the software which makes and maintains relevé databases. It helps users input and accumulate relevé data from field records and literature in database files. FVT is the software which makes and edits community tables. It can import relevé data selected with certain conditions from a database file into a community table. Both FVD and FVT can export data in text or csV format. A relevé datum comprises the ID no., survey date, surveyor name, references, remarks, surveyed area, location (place name, ID no. of Standard Area Grid square, longitude, latitude, elevation), environmental data (inclination, aspect, topography, surface geology, soil type), community-structural data (height and vegetation cover of each layer of tree-1 and -2 , shrub- 1 and -2 , herb-1 and -2 , and moss), and floristic data (species no., species name, dominace and sociability).

The advantages of PRDB over MVDB were demonstrated by analyzing the distribution of buna and mizunara (Shimada et al. 2004). The potential distribution of individual buna trees based on PRDB was compared with that of buna forests based on MVDB, showing that the thermal range for the individual trees was wider than that for the forests (Matsui et al. 2005).

\section{Other Useful Information on Plant/vegetation Distribution}

There are some other sources of information on plant/vegetation distribution useful for studies on predicting the potential distribution. Different types of information can be used for studies on various scales (Table 1).

NSNE digital vegetation maps (PVDB) made in 1999 have not been utilized for the study. They may be useful to analyze fragmented vegetation patches, most of which are not expressed in MVDB although both of them were made from the NSNE printed vegetation maps. Fragmented vegetation patches include evergreen lucidophyll forests, which occur in highly populated areas, Abies mariesii forests, which occur in subalpine areas with heavy snow accumulation, and alpine vegetation.

Other information which may be useful for the study are 1:500,000 printed vegetation maps (Miyawaki 1980-1989), 1:15 million printed plant distribution maps (Horikawa 1972, 1976), distribution records of conifers (Hayashi 1951, 1952, 1954), and various local flora records. They have not been digitized but provide important data on plant/vegetation distribution.

\section{Environmental Data}

Environmental data associating plant/vegetation data are essential for parameterizing statistical distribution models (Table 2). Data from the Climate Normals (Anon. 1996), Digital Map 50-m Grid (Anon. 2000), the Digital National Land Information (Anon. 1979) and a climate change scenario CCSR/NIES (Yokozawa et al. 2003) were used in the previous studies (Matsui et al. 2004a, 2004b, Yagihashi et al. 2003, 2004). Data from Digital Map 50-m Grid were used for calculating aspect and inclination at the vegetation 
Table 1. Available plant/vegetation information useful for studies on predicting distribution under changing climate.

\begin{tabular}{|c|c|c|c|c|c|}
\hline $\begin{array}{l}\text { Plant/vegetation } \\
\text { information }\end{array}$ & $\begin{array}{l}\text { Scale } \\
\text { (Area) }\end{array}$ & $\begin{array}{l}\text { Spatial } \\
\text { resolution }\end{array}$ & Attribute of information & $\begin{array}{l}\text { Form of } \\
\text { information }\end{array}$ & Data source \\
\hline $\begin{array}{l}\text { NSNE }{ }^{\prime \prime} \text { third mesh } \\
\text { vegetation database } \\
\text { (MVDB) }\end{array}$ & $\begin{array}{l}\text { Whole } \\
\text { Japan, }\end{array}$ & $\begin{array}{l}\text { Ca. } 1-\mathrm{km} \\
\text { grid } \\
\text { on } 1: 50,000 \\
\text { maps }\end{array}$ & $\begin{array}{l}\text { Vegetation type for every } \\
1-\mathrm{km} \text { square }\end{array}$ & $\begin{array}{l}\text { Text data } \\
\text { (code) }\end{array}$ & $\begin{array}{l}\text { Anon. 1988, Ministry } \\
\text { of Environment }\end{array}$ \\
\hline $\begin{array}{l}\text { NSNE digital } \\
\text { vegetation map } \\
\text { database (PVDB) }\end{array}$ & $\begin{array}{l}\text { Whole } \\
\text { Japan }\end{array}$ & $\begin{array}{l}\text { Based on } \\
1: 50,000 \\
\text { maps }\end{array}$ & $\begin{array}{l}\text { Vegetation type for every } \\
\text { patch }\end{array}$ & Polygon data & $\begin{array}{l}\text { Anon. 1988, Anon. } \\
1999\end{array}$ \\
\hline $\begin{array}{l}\text { Phytosociological } \\
\text { relevé database } \\
\text { (PRDB) }\end{array}$ & $\begin{array}{l}\text { Whole } \\
\text { Japan }\end{array}$ & $\begin{array}{l}\text { Plots usually } \\
\text { less than } \\
600 \mathrm{~m}^{2}\end{array}$ & $\begin{array}{l}\text { Relevé information } \\
\text { (Description of } \\
\text { vegetation) }\end{array}$ & Text data & $\begin{array}{l}\text { Various literature and } \\
\text { field survey records }\end{array}$ \\
\hline Vegetation maps & $\begin{array}{l}\text { Whole } \\
\text { Japan }\end{array}$ & & $\begin{array}{l}\text { Vegetation type for every } \\
\text { patch }\end{array}$ & $\begin{array}{l}1: 500,000 \\
\text { printed maps }\end{array}$ & Miyawaki 1980-1989 \\
\hline $\begin{array}{l}\text { Plant distribution } \\
\text { maps }\end{array}$ & $\begin{array}{l}\text { Whole } \\
\text { Japan }\end{array}$ & $\begin{array}{l}\text { Ca. 20-km } \\
\text { grid }\end{array}$ & $\begin{array}{l}\text { Horizontal and elevational } \\
\text { distribution of species }\end{array}$ & $\begin{array}{l}1: 15,000,000 \\
\text { printed maps }\end{array}$ & Horikawa 1972, 1976 \\
\hline $\begin{array}{l}\text { Distribution records } \\
\text { of conifers }\end{array}$ & $\begin{array}{l}\text { Whole } \\
\text { Japan }\end{array}$ & Various & $\begin{array}{l}\text { Location names } \\
\text { (townships, mountains, } \\
\text { catchments etc.) and } \\
\text { elevational ranges for } \\
\text { species }\end{array}$ & $\begin{array}{l}\text { Printed } \\
\text { reports }\end{array}$ & $\begin{array}{l}\text { Hayashi 1951, } 1952 \\
\text { and } 1954\end{array}$ \\
\hline Local flora reports & $\begin{array}{l}\text { Local } \\
\text { areas }\end{array}$ & Various & $\begin{array}{l}\text { Distribution of plant } \\
\text { species }\end{array}$ & $\begin{array}{l}\text { Printed } \\
\text { reports }\end{array}$ & $\begin{array}{l}\text { Cf. Ikegami \& } \\
\text { Ishizawa 1980-2000, } \\
\text { Flora-Kanagawa } \\
\text { Association. 2001, }\end{array}$ \\
\hline
\end{tabular}

Table 2. Available environment information useful for studies on predicting distribution under changing climate.

\begin{tabular}{|c|c|c|c|c|c|}
\hline $\begin{array}{l}\text { Environment } \\
\text { information }\end{array}$ & $\begin{array}{l}\text { Scale } \\
\text { (Area) }\end{array}$ & $\begin{array}{l}\text { Spatial } \\
\text { resolution }\end{array}$ & Attribute of information & $\begin{array}{l}\text { Form of } \\
\text { information }\end{array}$ & Data source \\
\hline Climate Normals & $\begin{array}{l}\text { Whole } \\
\text { Japan }\end{array}$ & Ca. 1-km grid" & $\begin{array}{l}\text { Monthly means of daily maximum, } \\
\text { minimum and average temperature, } \\
\text { monthly precipitation and monthly } \\
\text { maximum snow depth }\end{array}$ & Text data & Anon. 1996 \\
\hline $\begin{array}{l}\text { Digital Map 50-m } \\
\text { Grid }\end{array}$ & $\begin{array}{l}\text { Whole } \\
\text { Japan }\end{array}$ & Ca. 50-m grid & Elevation & Text data & Anon. 2000 \\
\hline $\begin{array}{l}\text { Digital National } \\
\text { Land Information }\end{array}$ & $\begin{array}{l}\text { Whole } \\
\text { Japan }\end{array}$ & $\begin{array}{l}\text { Ca. 1-km grid }{ }^{\prime)} \\
\text { based on } \\
1: 50,000 \text { Land } \\
\text { Classification } \\
\text { Maps }\end{array}$ & $\begin{array}{l}\text { Topography, surface geology and } \\
\text { soil types for every } 1-\mathrm{km} \text { square }\end{array}$ & $\begin{array}{l}\text { Text data } \\
\text { (code) }\end{array}$ & $\begin{array}{l}\text { Anon. } 1979, \\
\text { Yoshinaga et } \\
\text { al. } 1994\end{array}$ \\
\hline $\begin{array}{l}\text { Climate change } \\
\text { scenarios NIES } \\
\text { (CCSR-98, } \\
\text { CSIRO-MK2, } \\
\text { ECHM4/OPYC3, } \\
\text { CGCM1) }\end{array}$ & $\begin{array}{l}\text { Whole } \\
\text { Japan }\end{array}$ & Ca. 10-km grid $^{2)}$ & $\begin{array}{l}\text { Monthly means of daily maximum, } \\
\text { minimum and average temperature } \\
\text { and monthly precipitation }\end{array}$ & Text data & $\begin{array}{l}\text { Yokozawa et } \\
\text { al. } 2003\end{array}$ \\
\hline $\begin{array}{l}\text { Land Classification } \\
\text { Maps }\end{array}$ & $\begin{array}{l}\text { Whole } \\
\text { Japan }\end{array}$ & $\begin{array}{l}\text { Based on } \\
1: 50,000 \text { maps }\end{array}$ & $\begin{array}{l}\text { Patches of topography, surface } \\
\text { geology and soil types }\end{array}$ & $\begin{array}{l}1: 200,000 \\
\text { printed } \\
\text { maps }\end{array}$ & $\begin{array}{l}\text { Anon. } \\
1970-1978 .\end{array}$ \\
\hline $\begin{array}{l}\text { Climate change } \\
\text { scenario } \\
\text { MRI-RSM20KM }\end{array}$ & $\begin{array}{l}\text { Whole } \\
\text { Japan }\end{array}$ & Ca. $20-\mathrm{km}$ grid & $\begin{array}{l}\text { Daily maximum, minimum and } \\
\text { average temperature and monthly } \\
\text { precipitation, etc. }\end{array}$ & Text data & Unpublished \\
\hline
\end{tabular}

1) third mesh in the Standard Area Grid System (Anon. 1998), ${ }^{2)}$ second mesh in the SAGS. 
sampling areas (a 125-m radius circle centered on each square) to standardize MVDB and the elevational data. The Digital National Land Information is $1-\mathrm{km}$ grid data summarized from printed Land Classification Maps with standardized classification systems for geology, topography and soil (Yoshinaga et al. 1994). Climatic variables for every $1-\mathrm{km}$ grid square were interpolated from the climate change scenario CCSR/NIES (10-km grid) to fit the spatial resolution of MVDB.

Land Classification Maps, from which the 1-km grid data set (the Digital National Land Information) were derived, are useful for the analysis at higher spatial resolution if they are digitized into polygon data. A new climate change scenario MRI-RSM20KM (20-km grid) based on the emission scenario SRES-A2 (IPCC 2001) was recently made by the Metrological Research Institute for further studies on the impact assessment of climate changes.

\section{Conclusion}

Using the NSNE 3rd mesh vegetation database (MVDB) at ca. 1-km mesh, statistical distribution models were developed to predict potential habitat distributions for buna forests and mizunara forests, and also for buna forests under the current climate and an anticipated climate in the 2090s. These studies showed that MVDB was useful to predict the potential distribution of the forest types on a nation-wide scale. However, MVDB has some disadvantages, such as a lack of information on plant species distribution for more detailed analysis. We have been constructing a phytosociological relevé database (PRDB) to compensate for the disadvantages of MVDB. We expect PRDB to enable us to parameterize the statistical models to predict potential distributions of plant species on different spatial scales. Other information useful for the study includes a variety of vegetation maps, plant distribution maps and local flora reports. Vegetation databases constructed with the different types of information are useful to analyze the distributional relationships between various plant species (or vegetation types) and environmental factors at various spatial resolutions and in various study areas.

\section{References}

Anon., 1967: Guideline on field surveys for compiling land classification map series at 1:200,000. Land Survey Division Letter No. 219 (August 2), Tokyo (in Japanese).

Anon. 1979. Digital national land information: Land classification KS-156-1. Japan Map Centre, Tokyo (in Japanese).

Anon., 1970-1978: Land Classification Map. 47 Prefectures. National Land Agency, Japan (in Japanese).
Anon., 1988: Report of the vegetation investigation for the 3rd. National Survey on the Natural Environment. Asia Air Survey, Tokyo, (in Japanese).

Anon., 1996: Climate normals for Japan. Japan Meteorological Agency, Tokyo.

Anon., 1998: Numerical Map Users Guide, 2nd Version. Japan Meteorological Agency, Tokyo (in Japanese).

Anon., 1999: The Dataset for GIS on the Natural Environment, Japan (ver. 2). Ministry of Environment.

Anon., 2000: Digital Map 50-m Grid (Elevation). Geographical Survey Institute, Tsukuba, Ibaraki (in Japanese).

Bolliger, J., Kienast, F. and Bugmann, H. 2000. Comparing models for tree distributions: concept, structures, and behavior. Ecological Modeling 134, 89-102.

Braun-Blanquet, J., 1964: Pflanzensoziologie, Grundzuge der Vegetationskunde, 3. Aufl. Springer-Verlag, Wien and New York, 865pp.

Brzeziecki, B. Kienast, F. and Wildi, O., 1993: A simulated map of the potential natural forest vegetation of Switzerland. Journal of Vegetation Science 4: 499-508.

Flora-Kanagawa Association., 2001: Flora of Kanagawa 2001. Kanagawa Prefectural Museum of Natural History, 1580pp. (in Japanese).

Franklin, J., 1998: Predicting the distribution of shrub species southern California from climate and terrain-derived variables. Journal of Vegetation Science 9, 733-748.

Guisan, A. and Theurillat, J.-P., 2000: Equilibrium modeling of alpine plant distribution: how far can we go. Phytocoenologia 30, 353-384.

Hayashi, Y., 1951: The natural distribution of important trees, indigenous to Japan. Conifer report 1. Bulletin of the Government Forest Experiment Station 48, 1-239 (in Japanese).

Hayashi, Y., 1952: The natural distribution of important trees, indigenous to Japan. Conifer report 2. ibid. 55, 1-251 (in Japanese).

Hayashi, Y. 1954. The natural distribution of important trees, indigenous to Japan. Conifer report 3. ibid. 75, 1-173 (in Japanese).

Horikawa, Y., 1972, 1976: Atlas of the Japanese Flora: an introduction to plant sociology of East Asia, Vol. 1 and 2. Gakken, Tokyo., 862pp.

Ikegami, Y. and Ishizawa, S., 1980-2000: Distribution Maps of Vascular Plants in Niigata Prefecture (Japan), Vol. 1-20. Jinenjo-kai, Niigata (in Japanese).

IPCC., 2001: Climate Change 2001: The Scientific Basis. Cambridge University Press, $881 \mathrm{pp.}$

Iverson, L. R. and Prasad, A. M., 1998: Predicting abundance of 80 tree species following climate change in the eastern United States. Ecological Monographs 68, 465-485.

Iverson, L. R., Prasad, A. M., Hale, B. J., and 
Sutherland, E. K., 1999: An atlas of current and potential future distributions of common trees of the eastern United States. General Technical Report $N E$-265. Northeastern Research Station, USDA Forest Service.

Leathwick, J. R., 1995: Climatic relationships of some New Zealand forest tree species. Journal of Vegetation Science 6, 237-248.

Leathwick, J. R., Whitehead, D., McLeod, M., 1996: Predicting changes in the composition of New Zealand's indigenous forests in response to global warming: a modeling approach. Environmental Software 11, 81-90.

Lehmann, A., Leathwick, J. R. and Overton, J. Mc.C., 2002: Assessing New Zealand fern diversity from spatial predictions of species assemblages. Biodiversity and Conservation 11, 2217-2238.

Matsui, T., Yagihashi, T., Nakaya, T., Tanaka, N. and Taoda, H., 2004a: Climatic controls on distribution of Fagus crenata forests in Japan. Journal of Vegetation Science 15, 57-66.

Matsui, T., Yagihashi, T., Nakaya, T., Taoda, H., Yoshinaga, S., Daimaru, H., Tanaka, N.: 2004b. Probability distributions, vulnerability and sensitivity in Fagus crenata forests following predicted climate changes in Japan. Journal of Vegetation Science 15: 605-614.

Matsui T., Nakaya T., Yagihashi T., Taoda H., Tanaka N.: 2004c. Comparing accuracy of predictive distribution models for Fagus crenata forests. Japanese Journal of Forest Environment 46(2), in press.

Matsui, T., Shimada, K., Yagihashi, T., Nakaya, T., Taoda, H. and Tanaka, N.: 2005. Assessing potential distribution of Fagus crenata in central Japan. $J$. Agric. Meteorol 60, (this issue).

Miyawaki, A., 1980-1989: Vegetation of Japan, Vol. I-10. Shibundo, Tokyo (in Japanese).

Shimada, K., Tanaka, N., Tsuyama, I. and Taoda, H., 2004: Advantages of vegetation data in analyzing the relation between climate and distribution of Fagus crenata and Quercus mongolica var. grosseserrata. Tans. Mtg Br. Jpn. For. Soc. 55: 183-185 (in Japanese).

Tanaka, N., 2003: Studies on impact assessment of global warming based on vegetation database. Shokusei-Joho 7, 10-14 (in Japanese).

Thompson, R. S., Hostetler, S. W., Bartlein, P. J. and Anderson, K. H., 1998: A strategy for assessing potential future changes in climate, hydrology, and vegetation in the Western United States. U.S. Geological Survey Circular 1153, 20pp.

Thompson, R. S., Anderson, K. H. and Bartlein, P. J., 1999: Atlas of relations between climatic parameters and the distribution of important trees and shrubs in North America. U.S. Geological Survey Professional Paper 1650A and B.

Yagihashi, T., Matsui, T., Nakaya, T., Taoda, H. and Tanaka, N., 2003: Classification of Fagus crenata forests and Quercus mongolica var. grosseserrata forests with regard to climatic conditions. Japanese Journal of Ecology 53, 85-94 (in Japanese).

Yagihashi, T., Matsui, T., Nakaya, T., Taoda, H., and Tanaka, N., 2004: Climatic controls differentiating the distributions of Fagus crenata forests and Quercus mongolica var. crispula forests in Japan. Proceedings of Oak 2003, Japan: a joint meeting of IUFRO working groups, genetics of Quercus \& improvement and silviculture of oaks. FFPRI Scientific Meeting Report. (in press).

Yokozawa, M., Goto, S., Hayashi, Y. and Seino, H., 2003: Mesh climate data for evaluating climate change impacts in Japan under gradually increasing CO2. J. Agric. Meteorol. 59: 117-130.

Yoshinaga, S., Suzuki, Y., Matsukura, Y., Kobayashi, M. and Arai, T., 1994: Mapping of relative sensitivity to acid deposition for Japan Island by utilizing Digital National Land Information. Jpn. J. Soil Sci. Plant Nutr 65, 565-568 (in Japanese). 